\title{
LA PARTICIPACIÓN DE EXTRANJEROS \\ EN SOCIEDADES CIVILES O MERCANTILES PROPIETARIAS \\ DE TIERRAS EN MÉXICO: TRATAMIENTO DE POSIBLES CONTROVERSIAS EN EL MARCO DEL TLCAN
}

\section{Aldo Saúl MuÑOZ LÓPEZ*}

RESUMEN: Este trabajo aborda el tratamiento de controversias que, a través del arbitraje internacional, puede promover un inversionista extranjero el cual, de acuerdo con el artículo 130 de la Ley Agraria, participa en sociedades civiles o mercantiles propietarias de tierras agrícolas, ganaderas o forestales, al considerar que ha sufrido daño o pérdida en sus inversiones con motivo del incumplimiento de las obligaciones de México como Estado huésped de la inversión, en términos del capítulo XI, sección B, del Tratado de Libre Comercio de América del Norte. Constituye una reflexión propositiva a la luz de los laudos arbitrales dictados en contra del Estado mexicano.

ABSTRACT: This work deals with the disputes that foreign investors participating in civil or commercial societies that hold land for agricultural, forest or cattle exploitation under article 130 of Agrarian Legislation, may initiate through international arbitration. This would be the case of damage or losses of the investment due to the breach of Mexico's obligations as the host state, in terms of NAFTA's Chapter XI, Section B. This constitutes a suggestive reflection in light of arbitral awards issued against the Mexican Government.

RÉSUMÉ: Cette étude traite de l'arbitrage internationale des controverses nées de la participation d'un investisseur étranger dans des sociétés civiles ou commerciales, dans le cadre de l'article 130 de la Loi mexicaine sur l'agriculture, lorsque ces sociétés sont propriétaires de terres agricoles, de pâturages ou de forêts. Ces controverses naissent quand l'investisseur étranger estime qu'il a subi un dommage ou une perte dans ses investissements suite au non-respect de ses obligations par le Mexique, celui-ci étant considéré l'État hôte de l'investissement aux termes du Chapitre XI, Section B de l'Accord de Libre Échange d'Amérique du Nord, ALENA. Au-delà de la réflexion, l'auteur émet des propositions à la lumière des décisions d'arbitrage internationale rendues contre l'État mexicain.

* Magistrado en el Tribunal Unitario Agrario en Hermosillo, Sonora, México. 
Al doctor Jorge Witker, respetable maestro, jurista e investigador distinguido, en agradecimiento a su apoyo y orientaciones académicas.

SUMARIO: I. Introducción. II. Planteamiento del problema. III. Marco constitucional aplicable al tema. IV. La Convención de Viena. V. Ley sobre Celebración de Tratados. VI. Tratado de Libre Comercio para América del Norte. VII. La Ley de Inversión Extranjera. VIII. La Suprema Corte de Justicia de la Nación. IX. La Ley Agraria. X. Sociedades comerciales propietarias de tierras. XI. El Centro Internacional de Arreglo de Diferencias relativas a Inversiones (CIADI). XII. El arbitraje como mecanismo de solución de controversias. XIII. Los Acuerdos de Promoción y Protección de Inversiones (Apris). XIV. El caso Punta Banda. XV. Conclusiones. XVI. Sugerencias. XVII. Bibliografía.

\section{INTRODUCCIÓN}

El objetivo general de este trabajo radica en analizar el tratamiento de controversias que puede promover un inversionista extranjero que participa en sociedades mercantiles o civiles propietarias de tierras agrícolas, ganaderas o forestales, al sufrir daño o pérdida con motivo de incumplimiento de México como Estado huésped de la inversión, en términos del capítulo XI, sección B, del Tratado de Libre Comercio de América del Norte (TLCAN).

Uno de sus objetivos particulares consiste en analizar el marco jurídico vigente en México que permite la participación de extranjeros en esas sociedades comerciales, así como destacar sus repercusiones económicas y sociales. Otro objetivo específico radica en explicar el arbitraje y su procedimiento como mecanismo de solución a posibles controversias derivadas de la inversión extranjera, y finalmente comentar los alcances del laudo arbitral que en su caso se dicte.

El punto de partida de esta investigación radica en que el marco constitucional y legal agrario mexicano permite que extranjeros puedan formar parte de ese tipo de sociedades comerciales. Esta participación abre la posibilidad de que, si un extranjero considera que ha sufrido daño o pérdida en su inversión (que se da a través de acciones o partes sociales de serie " $\mathrm{T}$ "), pueda demandar al Estado mexicano como Estado receptor 
de la inversión (ya sea a nivel municipal, estatal o federal), ante las instancias internacionales establecidas en el capítulo XI del TLCAN.

La perspectiva epistemológica de este trabajo se inscribe, por una parte, en la corriente teórica del positivismo, ${ }^{1}$ esto en virtud de que se toman como referencias de estudio algunos preceptos de la Constitución Política de los Estados Unidos Mexicanos, así como el capítulo XI del TLCAN y una serie de leyes federales vigentes en nuestro país; y por la otra, en el enfoque del realismo jurídico, ${ }^{2}$ ya que se abordan las consecuencias sociales y económicas que se producen con la participación de extranjeros en sociedades civiles o mercantiles propietarias de tierras en nuestro país.

No obstante lo anterior, esta investigación es de tipo jurídica-propositiva, pues en una parte cuestiona la fracción IV, del artículo 27 constitucional, y algunas disposiciones de la Ley Agraria, evaluando sus efectos y consecuencias a la luz de un contexto nacional e internacional; y en la otra propone cambios o reformas legislativas con el fin de que las sociedades civiles o mercantiles no sean propietarias de tierras, y más todavía que no se permita la participación de extranjeros en las mismas.

Los métodos básicamente aplicados son la dogmática jurídica ${ }^{3}$ y la crítica, ya que se sistematizan e interpretan disposiciones jurídicas aplicables en este tipo de controversias. Las técnicas de investigación utilizadas

1 Sánchez Vázquez, Rafael, La libertad e igualdad jurídica como principios generales del derecho, Porrúa, México, 1995, p. 44. "El positivismo jurídico rompe con el esquema valorativo y subjetivo del iusnaturalismo. Dicho de otra manera, para los juristas que cultivan y comparten la teoría positivista y neopositivista del derecho, lo que a éstos más les interesa es describir el derecho como objeto de estudio de acuerdo a sus formas de elaboración y aplicación en un espacio y tiempo histórico concreto.

2 Sánchez Vázquez, Rafael, Metodología de la ciencia del derecho, 5a. ed. corr. y aum., México, Porrúa, 2001, p. 228. "Los cultores del realismo jurídico consideran que la tarea fundamental del jurista descansa tanto en el estudio y análisis crítico del lenguaje jurídico y su implicación con la realidad social. Igualmente, se ocupan de los hechos sociales y del funcionamiento real de lo que acontece en los tribunales y de los múltiples factores, muchas veces aparentemente desconectados de lo jurídico, pero que influyen en las decisiones de los jueces, magistrados... por lo tanto, se torna prudente destacar que para los cultores del realismo jurídico, el derecho no sólo es un discurso normativo, lógico y abstracto, sino que implica aún todo complejo, vivo y actuante en una realidad histórica concreta. De ahí, el interés de los realistas de dar más énfasis al hecho concreto, el estudio del caso... de esa manera, el derecho tiene un carácter eminentemente judicial y práctico".

3 Arnaud, André-Jean et al. (eds.), Dictionaire encyclopédique de théorie es de sociologie du droit, 2a. ed., París, Librairie Générale de Droit et de Jurisprudence, 1993, p. 188. Citado por LópezAyllón, Sergio, Las transformaciones del sistema jurídico y los significados sociales del derecho en México. La encrucijada entre tradición y modernidad, México, UNAM, Instituto de Investigaciones Jurídicas, 1997, p. 1. "La dogmática jurídica es la rama de la ciencia del derecho que tiene como objeto la interpretación y la sistematización de las normas jurídicas". 
son: la documental bibliográfica y hemerográfica a través de consultas a libros, revistas, periódicos y páginas de Internet.

El tema que nos ocupa fue materia de estudio en la asignatura Mecanismos Alternativos para la Resolución de Conflictos Comerciales, que imparte el profesor Jorge Witker en el Doctorado en Derecho, con línea de investigación en derecho económico, que oferta la Universidad Autónoma de Puebla.

\section{PLANTEAMIENTO DEL PROBLEMA}

La reforma al artículo 27 de la Constitución Política de los Estados Unidos Mexicanos, ${ }^{4}$ y la promulgación de la Ley Agraria, ${ }^{5}$ entre otras disposiciones jurídicas, ${ }^{6}$ fueron ajustes necesarios para adecuar la estructura constitucional, y lograr así la firma del TLCAN ${ }^{7}$ que entró en vigor el 1o. de enero de 1994.

Estos acontecimientos, y otros, constituyeron nuevas bases jurídicas para la consolidación de un modelo neoliberal y de políticas económicas de apertura comercial impuestas al gobierno mexicano por el Banco Mundial (BM), el Fondo Monetario Internacional (FMI), y el Banco Interamericano de Desarrollo (BID), desde hace aproximadamente veinte años.

Esas políticas de ajuste hacia el interior y acondicionamiento hacia el exterior han abierto la posibilidad jurídica para que extranjeros ${ }^{8}$ puedan ser socios en sociedades mercantiles o civiles propietarias de tierras. El único límite impuesto es que esa participación extranjera no exceda el $49 \%$ de acciones o partes sociales de series " $\mathrm{T}$ ".

En el marco del TLCAN, concretamente en su capítulo XI, por un lado tenemos que la inversión en sí y la inversión de extranjeros como inversionistas, son factores claves que inciden directamente en la economía y en la política de los mexicanos; y por el otro, observamos que el tratamiento de dichos factores por el gobierno mexicano está generando controversias cuyo tratamiento y solución no corresponde definitivamen-

4 Decreto publicado en el Diario Oficial de la Federación el 6 de enero de 1992.

5 Decreto publicado en el Diario Oficial de la Federación el 26 de febrero de 1992.

6 Ley Forestal, publicada en el Diario Oficial de la Federación el 22 de diciembre de 1992.

7 Decreto publicado en el Diario Oficial de la Federación el 20 de diciembre de 1993.

8 Conforme a la fracción IV, del artículo 2o. de la Ley de Nacionalidad, extranjero es quien no tiene la nacionalidad mexicana. 
te a los tribunales establecidos en nuestro país, por lo que los resultados hasta hoy obtenidos nos obligan a estudiar con mayor interés el contenido y trascendencia del TLCAN, de manera más concreta, su capítulo XI.

En resumen, el tema a investigar es el tratamiento jurídico de las controversias que se pueden presentar por un inversionista extranjero que participa en una sociedad civil o mercantil propietaria de tierras agrícolas, ganaderas o forestales, al considerar que su inversión ha sufrido daño o pérdida con motivo de incumplimiento a una de las obligaciones pactadas por parte de México como Estado huésped de la inversión; esto en función de las graves consecuencias económicas y sociales que producen esos conflictos al pueblo mexicano, quien de una o otra manera es quien paga las consecuencias de las políticas aplicadas por el gobierno neoliberal proclive a la "globalización".

\section{MARCO CONSTITUCIONAL APLICABLE AL TEMA}

La Constitución Política de los Estados Unidos Mexicanos es nuestra ley fundamental. Los sujetos de la Constitución son: El Estado y el gobernado. El Estado mexicano es el Estado huésped de la inversión extranjera, y el inversionista extranjero que participa en la sociedad civil propietaria de tierras es el gobernado.

\section{Principio de supremacía constitucional}

El artículo 133 de la Constitución Política de los Estados Unidos Mexicanos contiene el principio de supremacía constitucional. A la letra dice:

Esta constitución, las leyes del Congreso de la Unión, que emanen de ella y todos los tratados que estén de acuerdo con la misma, celebrados y que se celebren por el Presidente de la República, con aprobación del Senado, serán la ley suprema de toda la Unión. Los jueces de cada Estado se arreglarán a dicha constitución, leyes y tratados a pesar de las disposiciones en contrario que pueda haber en las constituciones o leyes de los Estados.

\section{La cláusula Calvo}

El artículo 27 constitucional, en su fracción I, contiene la Cláusula Calvo. Esta parte del precepto dice: 
Sólo los mexicanos por nacimiento o por naturalización y las sociedades mexicanas tienen derechos para adquirir el dominio de las tierras, aguas y sus accesiones o para obtener concesiones de explotación de minas o aguas. Asimismo, el estado podrá conceder el mismo derecho a los extranjeros siempre que convengan ante la Secretaría de Relaciones en considerarse como nacionales respecto de dichos bienes y en no invocar, por lo mismo, la protección de sus gobiernos por lo que se refiere a aquéllos; bajo la pena, en caso de faltar al convenio, de perder en beneficio de la nación, los bienes que hubieren adquirido en virtud de lo mismo. En una franja de cien kilómetros a lo largo de la frontera y de cincuenta en las playas, por ningún motivo podrán los extranjeros adquirir el dominio directo sobre sus tierras y aguas.

\section{El artículo 27 constitucional, antes del 6 de enero de 1992}

Literalmente su fracción IV decía así:

Las sociedades comerciales por acciones, no podrán adquirir, poseer o administrar fincas rústicas, las sociedades de esta clase que se constituyeren para explotar cualquier industria fabril, minera, petrolera o para algún otro fin que no sea agrícola, podrán adquirir, poseer o administrar terrenos únicamente en la extensión que sea estrictamente necesaria para los establecimientos o servicios de los objetos indicados, que el ejecutivo de la unión o los Estados, fijarán en cada caso.

\section{El artículo 27 constitucional, después del 6 de enero de 1992}

En su fracción IV, actualmente dice:

Las sociedades mercantiles por acciones podrán ser propietarias de terrenos rústicos pero únicamente en la extensión que sea necesaria para el cumplimiento de su objeto.

En ningún caso, las sociedades de esta clase podrán tener en propiedad tierras dedicadas a actividades agrícolas, ganaderas o forestales en mayor extensión que la respectiva equivalente a veinticinco veces los límites señalados en la fracción XV de este artículo. La ley reglamentaria regulará la estructura de capital y el número mínimo de socios de estas sociedades, a efecto de que las tierras propiedad de la sociedad no excedan en relación con cada socio los límites de la pequeña propiedad. En este caso, toda propiedad accionaria individual, correspondiente a terrenos rústicos, será acumulable para efectos de cómputo. Asimismo, la ley señalará las condiciones para la participación extranjera en dichas sociedades. 
La propia ley establecerá los medios de registro y control necesarios para el cumplimiento de lo dispuesto por esta fracción.

\section{LA CONVENCIÓN DE VIENA}

La Convención de Viena sobre el Derecho de los Tratados fue aprobada en la Ciudad del mismo nombre por diecinueve Estados, entró en vigor el 20 de Enero de 1980, al computarse las 35 ratificaciones necesarias. Cerca de cuarenta países han suscrito esta Convención, estando México entre ellos.

La convención regula la creación, interpretación, modificación y terminación y obligatoriedad de los tratados, y han contribuido a una mayor y mejor utilización de los instrumentos internacionales por parte de los Estados, ya que cuentan con una mayor seguridad jurídica de la que se ofrecía antes con los acuerdos derivados exclusivamente en el derecho consuetudinario.

La Convención de Viena en el artículo segundo establece que se entiende por tratado, un acuerdo internacional celebrado por escrito entre Estados, cualquiera que sea su denominación particular. De lo anterior se concluye que no importa se le designe acuerdo, pacto, convención, o convenio, ya que tendrá los mismos efectos jurídicos que un tratado. ${ }^{9}$

\section{LEY SOBRE CELEBRACIÓN DE TRATADOS}

En cuanto a nuestra regulación en la materia, en el DOF del 2 de enero de 1992, se publicó la Ley sobre Celebración de Tratados, en la cual, por primera vez en nuestra historia, se regulan los acuerdos ejecutivos bajo la denominación de acuerdos interinstitucionales, sin que se haya realizado ninguna reforma constitucional sobre el tema. ${ }^{10}$

Los citados autores sostienen que todo tratado internacional que celebre el presidente de la república debe ser aprobado por el Senado, de no ser así se violan los artículos 76, fracción I; 89, fracción X; y 133 constitucionales.

La tesis de los autores mencionados hace pensar que el TLCAN se firmó con base en la Ley sobre Celebración de Tratados, que fue promul-

9 Serrano Migallón, Fernando, El mecanismo de solución de controversias, en Witker, Jorge (coord.), Resolución de controversias comerciales en América del Norte, 1a. reimpr. de la 1a. ed., México, UNAM, Instituto de Investigaciones Jurídicas, 1997, pp. 68 y 69.

10 Ortiz Ahlf, Loretta et al., Aspectos jurídicos del Tratado de Libre Comercio de América del Norte y sus acuerdos paralelos, 1a. reimpr. de la 2a. ed., México, Themis, 2000, p. 7. 
gada sin que se haya hecho ninguna reforma constitucional sobre el tema, por lo que se presentan elementos que pueden conducir a la polémica en el sentido de que dicho tratado no tenga sustento legal ni constitucional.

\section{TRATADO DE LIBRE COMERCIO PARA AMÉRICA DEL NORTE}

El 1o. de enero de 1994 entró en vigor el Tratado del Libre Comercio de América del Norte (TLCAN), celebrado entre los Estados Unidos Mexicanos, Estados Unidos de América y Canadá. En inglés se le conoce por las siglas NAFTA (North América Free Trade Agreement).

\section{Estructura del TLCAN}

La estructura de este tratado se compone de un preámbulo y 22 capítulos distribuidos en ocho partes, más sus anexos. Los artículos se enumeran en función del capítulo que forman parte.

En primer lugar, el objeto principal del Tratado de Libre Comercio. Es el establecimiento de una zona de libre comercio. Este establecimiento implica que los Estados partes asuman determinadas obligaciones en variados aspectos: comercio de los bienes a circular, trato nacional y acceso al mercado nacional y al de los otros miembros, comercio e inversión, procedimientos aduaneros, las cuestiones relacionadas con el dumping, determinación de un régimen de origen de las mercancías, medidas sobre el sector agropecuario, energético, petroquímico, barreras al comercio, compras del sector público, medidas relativas a la normalización, comercio fronterizo, telecomunicaciones, servicios financieros, propiedad industrial, aspectos laborales, aspectos ecológicos, y finalmente lo referente a la solución de controversias que surjan con motivo de la administración del Tratado. ${ }^{11}$

\section{La inversión en el TLCAN}

De acuerdo con el tema que nos ocupa, es pertinente señalar que en la quinta parte del tratado se ubica el capítulo XI, que se refiere a la inversión, servicios y asuntos relacionados. Este capítulo a su vez se divide en secciones $\mathrm{A}, \mathrm{B}$ y $\mathrm{C}$.

11 Pacheco Martínez, Filiberto, Derecho de la integración económica, México, Porrúa, 1998, pp. 164 y 165. 
La sección A se refiere a la inversión, comprende del artículo 1101 al 1114. Esta sección hace referencia a que inversionistas de los países celebrantes del tratado reciban trato nacional (el mismo tratamiento que para los inversionistas nacionales); también se refiere al trato de la nación más favorecida (tratamiento igual al de cualquier otro país que sea más favorecido de sus inversionistas en el país anfitrión); tratamiento con las mínimas regulaciones del derecho internacional; prohibición contra requisitos de desempeño, tales como el de requerir un mínimo porcentaje de producción para exportar; libertad para seleccionar altos ejecutivos sin importar la nacionalidad, sujeto a ciertas excepciones respecto al número de mayoría en el consejo directivo; y libertad para transferir o repatriar ingresos o inversiones en una libre moneda cambiaria. Se proveen ciertas excepciones, como se refleja en los anexos del TLCAN o durante un periodo sin fase.

La sección B se refiere a la solución de controversias entre una parte y un inversionista de otra parte; comprende del artículo 1115 al 1137. Aquí se contienen las cláusulas de solución de controversias mixtas.

La sección C se refiere a definiciones, comprende los artículos 1138 y 1139. Y por último, sus anexos.

En el capítulo XI sobre la inversión, el inversionista de una parte que tenga una controversia con otra parte sobre inversiones hechas en ese país, puede someter la reclamación al arbitraje. Pudiendo escoger entre los tres principales sistemas de arbitraje existentes.

Puede someterlo al convenio del CIADI (Centro Internacional de Arreglo de Diferencias relativas a Inversiones). Esto procede cuando el Estado al que pertenece el inversionista y el Estado huésped de la inversión han firmado el Convenio de Washington. Puede someterlo a arbitraje bajo las Reglas del Mecanismo Complementario del CIADI. Esto opera cuando una de las partes ha celebrado el Convenio de Washington, ya sea el Estado al que pertenece el inversionista, o el Estado que recibe la inversión, (esto último es el caso de México). Puede someterlo a las Reglas del Arbitraje de la UNCITRAL (United Nations Commission on Internacional Trade Law). ${ }^{12}$

12 Witker, Jorge (coord.), Resolución de controversias comerciales en América del Norte. Panorama general de solución de controversias, 1a. reimpr. de la 1a. ed., México, UNAM, Instituto de Investigaciones Jurídicas, 1997, p. 65. 


\section{Comentarios al anexo 1120.1 del capítulo XI del TLCAN}

Este anexo regula los supuestos en que México, como parte del TLCAN, no puede ser sometido a un procedimiento arbitral, ya sea por un inversionista de otra parte que actúe por sí mismo o como propietario de una empresa establecida en México.

El primer supuesto establece que un inversionista de otra parte (canadiense o estadounidense), no podrá alegar que México ha violado una obligación establecida en la sección "A" del capítulo XI del TLCAN.

$\mathrm{Al}$ respecto, es dable señalar que las obligaciones establecidas son: que México como parte receptora de la inversión otorgará a los inversionistas de otra parte, un trato no menos favorable que el que otorgue a los inversionistas nacionales. A esto se le denomina trato nacional. Otra consiste en que México otorgará a los inversionistas de otra parte el mismo trato que otorgue a inversionistas de otras partes que no formen parte del TLCAN. A esto se le llama trato de nación más favorecida. Otra obligación es que México debe otorgar a los inversionistas y a las inversiones de los inversionistas de otra parte el mejor de los tratos. A esto se le denomina nivel de trato. Y la última obligación consiste en que México otorgará a las inversiones de los inversionistas de otra parte, un trato acorde con el derecho internacional. A esto se le llama nivel mínimo de trato.

De este primer supuesto, también se advierte que México no podrá ser sometido a la reclamación de arbitraje cuando el monopolio o empresa del Estado ha actuado de manera incompatible con las obligaciones antes mencionadas, en términos de los artículos 1502 (3) (a) y 1503/2.

Esta prohibición se establece tanto en un procedimiento arbitral como en procedimientos ante un tribunal judicial o administrativo de México.

El segundo supuesto previene que una empresa mexicana que sea una persona moral propiedad de un inversionista de otra parte o que esté bajo su control directo o indirecto, no podrá alegar que México ha violado las obligaciones previamente señaladas, ya sea en procedimientos ante un tribunal judicial o administrativo mexicano, o bien ante un procedimiento arbitral.

En síntesis, el anexo se refiere a excepciones por las que México no debe someterse a un procedimiento arbitral previsto en el capítulo XI, sección "B" del TLCAN. Para una mayor interpretación y comprensión de este anexo, es necesario recurrir a la lectura de lo previsto en el artículo 1120 del mismo capítulo en el cual se establece los casos en que un 
inversionista sí podrá demandar el sometimiento de México a la reclamación de arbitraje. Y en este caso, se aplican las reglas del mecanismo complementario del CIADI, tomando en cuenta que México no es parte del Convenio de Washington.

\section{LA LEY DE INVERSIÓN EXTRANJERA}

La Ley de Inversión Extranjera, publicada en DOF el 27 de diciembre de 1993 (anteriormente conocida como Ley para promover la Inversión Mexicana y Regular la Inversión Extranjera, publicada en el DOF el 9 de marzo de 1973). Sigue en vigor el Reglamento de la Ley anterior, publicado en el DOF el 16 de mayo de 1989.

Es conveniente mencionar que, en tanto la Constitución Política de los Estados Unidos Mexicanos, como la ley que regula la inversión extranjera establecen determinadas áreas en la economía en las cuales únicamente puede participar el Estado - estratégicas-, otras que están reservadas únicamente para los nacionales mexicanos - prioritarios_- y por último, otras en las que por regla general únicamente se permite participación de inversión extranjera hasta un $49 \%$, ya que esto es consecuencia del régimen proteccionista que ha tenido el Estado. Al respecto la legislación doméstica en materia de inversión extranjera contempla la posibilidad de que la Comisión Nacional de Inversiones Extranjeras (CNIE) (Álvarez Soberanis la califica como un organismo desconcentrado, intersecretarial, interdisciplinario y de alto nivel político) resuelva sobre el aumento o la disminución del porcentaje a que añaden los artículos 8 y 9 de la ley antes mencionada, cuando a su juicio sea conveniente para la economía del país y fije las condiciones conforme a las cuales se recibirá, en casos específicos, la inversión extranjera.

La adopción de la nueva Ley de Inversión Extranjera se llevó a cabo con la finalidad de facilitar el cumplimiento de los compromisos adquiridos con la firma del tratado Trilateral de Libre Comercio, uno de cuyos propósitos es la liberación de la economía y la privatización parcial o total de algunos sectores, lo cual a repercutido en mayores inversiones extranjeras.

A propósito, expresamos nuestra opinión en el sentido de que debe fomentarse el desarrollo económico privilegiando la participación de inversionistas mexicanos, ya sean públicos o privados, sin detrimento de la soberanía nacional y protegiendo la producción nacional, respecto de la inversión extranjera.

Debemos tomar en cuenta que la inversión extranjera no debe participar en todas las áreas de la economía mexicana, considerando lo que menciona Jaime Álvarez Soberanis, "la práctica de un gran número de países consis- 
tentes en que se reserven al Estado ciertas actividades económicas estratégicas, se justifica entre otras razones, por la necesidad de defender y conservar los recursos naturales no renovables que pudieran agotarse si se dejara en explotación a los particulares, ya sean nacionales o extranjeros". ${ }^{13}$

\section{La inversión}

La inversión es cualquiera clase de activo como inversiones en la creación, expansión o participación de una empresa y que pueda asumir distintas modalidades en los países huéspedes. ${ }^{14}$

Existen dos tipos de inversión: la productiva y la especulativa, a pesar de que desde un punto de vista individual, ambos tipos de inversión producen ganancias al inversionista, las economías de los Estados nacionales perciben a la inversión especulativa como simples transferencias de capital capitales golondrinos- que no constituyen una adición a su capacidad productiva. ${ }^{15}$

El TLC define el concepto de inversión en un sentido amplio. Para efectos del Tratado la inversión abarca todas las formas de propiedad y participación accionaria en las empresas, es decir, todas aquellas formas de propiedad tangible e intangible y aquellas que derivan de un contrato. ${ }^{16}$

\section{La inversión extranjera}

Son aquellas inversiones realizadas por un país o región específicas a través de las vías que señalen las leyes que impliquen transferencia de capital desde el interior, sea que el proyecto se efectúe directamente por los inversionistas extranjeros o mediante su asociación con un inversionista nacional. ${ }^{17}$

13 Véase Álvarez Soberanis, Jaime, El régimen jurídico y la política en materia de inversiones extranjeras en México, México, Themis, 1991, p. 168. Para el fundamento jurídico del derecho económico mexicano, véanse los artículos 25 y 28 de la Constitución Política de los Estados Unidos Mexicanos. Rodríguez González-Valadez, Carlos, México ante el arbitraje comercial internacional, México, Porrúa, 1999, pp. 22 y 23.

14 Witker, Jorge, "Aspectos regulatorios-institucionales de la inversión extranjera directa”, en Kaplan, Marcos y Manrique Campos, Irma (coords.), Regulación de flujos financieros internacionales, 2a. ed., México, UNAM, Instituto de Investigaciones Jurídicas, 2002, p. 80.

15 Bolaños Linares, Rigel, Inversión extranjera, México, Porrúa, 2002, pp. 99 y 100.

16 Rubio, Luis, ¿Cómo va a afectar a México el Tratado de Libre Comercio?, México, Fondo de Cultura Económica, 1994, pp. 260 y 261.

17 Witker, Jorge, op. cit., nota 14, p. 80. 


\section{La inversión extranjera directa}

Al analizar el tema de inversión extranjera hay que distinguir la inversión extranjera directa (IED), que es el capital productivo invertido a largo plazo de la inversión extranjera en cartera (mercado de dinero y mercado de capitales), que es una inversión de corto plazo básicamente especulativa, por que busca — atraída por la alta rentabilidad ofrecida en los mercados emergentes - la mayor ganancia en el menor tiempo posible.

La IED (Inversión Extranjera Directa) es aquella que tiene características de permanencia y materializa principalmente instalando una empresa nueva o ampliando una existente; mientras que la inversión de cartera o de portafolio, se orientan fundamentalmente a operaciones bursátiles en todas sus variantes y, preponderantemente, hacia diferentes actividades financieras y cambiarias. ${ }^{18}$

\section{El inversionista}

"Persona natural o jurídica de un país que actúa como sujeto que transfiere capitales con el carácter de inversión extranjera". ${ }^{19}$

Conforme el artículo 45 del Reglamento de la Ley de Inversión Extranjera, ante el Registro Nacional de Inversiones Extranjeras deberán inscribirse las protocolizaciones de cualquier documento o actas de asamblea, cuando personas morales extranjeras o físicas participen en la inversión extranjera en nuestro país.

Los fedatarios públicos están obligados a insertar en los instrumentos públicos otorgados ante ellos y en los que participe alguna de las personas obligadas a inscribirse en el Registro Nacional de Inversiones Extranjeras, una prevención que establezca la obligación de realizar la referida inscripción dentro del término legal. Ese parece ser el sentido del artículo 45 del Reglamento de la Ley de Inversión Extranjera, el cual sufre una pésima redacción, ausente de técnica jurídica y claridad conceptual. ${ }^{20}$

18 C. Korten, David, Cuando las transnacionales gobiernan el mundo, Chile, Ed. Cuatro Vientos, 1998, citado en ibidem, pp. 80 y 81.

19 Witker, Jorge, op. cit., nota 14, p. 80.

20 Robles Farías, Diego, El régimen jurídico de los extranjeros que participan en sociedades mexicanas, México, Themis, 2000, p. 62. 


\section{LA SUPREMA CORTE DE JUSTICIA DE LA NACIÓN}

Al interpretar el artículo 133 constitucional, la Suprema Corte de Justicia de la Nación, recientemente cambió su criterio en el que había establecido que las leyes federales y los tratados internacionales tenían la misma jerarquía normativa. Ahora sostiene el criterio de que los tratados internacionales están por encima de las leyes federales. Esto se ilustra en la siguiente jurisprudencia:

TRATADOS INTERNACIONALES. SE UBICAN JERÁRQUICAMENTE POR ENCIMA DE LAS LEYES FEDERALES Y EN UN SEGUNDO PLANO RESPECTO DE LA CONSTITUCIÓN FEDERAL. Persistentemente en la doctrina se ha formulado la interrogante respecto a la jerarquía de normas en nuestro derecho. Existe unanimidad respecto de que la Constitución federal es la norma fundamental y que aunque en principio la expresión “....serán la Ley Suprema de toda la Unión..." parece indicar que no sólo la Carta Magna es la suprema, la objeción es superada por el hecho de que las leyes deben emanar de la Constitución y ser aprobadas por un órgano constituido, como lo es el Congreso de la Unión y de que los tratados deben estar de acuerdo con la Ley Fundamental, lo que claramente indica que sólo la Constitución es la Ley Suprema. El problema respecto a la jerarquía de las demás normas del sistema, ha encontrado en la jurisprudencia y en la doctrina distintas soluciones, entre las que destacan: supremacía del derecho federal frente al local y misma jerarquía de los dos, en sus variantes lisa y llana, y con la existencia de "leyes constitucionales", y la de que será ley suprema la que sea calificada de constitucional. No obstante, esta Suprema Corte de Justicia considera que los tratados internacionales se encuentran en un segundo plano inmediatamente debajo de la Ley Fundamental y por encima del derecho federal y local. Esta interpretación del artículo 133 constitucional, deriva de que estos compromisos internacionales son asumidos por el Estado mexicano en su conjunto y comprometen a todas sus autoridades frente a la comunidad internacional; por ello se explica que el Constituyente haya facultado al presidente de la república a suscribir los tratados internacionales en su calidad de jefe de Estado y, de la misma manera, el Senado interviene como representante de la voluntad de las entidades federativas $\mathrm{y}$, por medio de su ratificación, obliga a sus autoridades. Otro aspecto importante para considerar esta jerarquía de los tratados, es la relativa a que en esta materia no existe limitación competencial entre la Federación y las entidades federativas, esto es, no se toma en cuenta la competencia federal o local del contenido del tratado, sino que por mandato expreso del propio artículo 133 el presidente de la república y el Senado pueden obli- 
gar al Estado mexicano en cualquier materia, independientemente de que para otros efectos esta sea competencia de las entidades federativas. Como consecuencia de lo anterior, la interpretación del artículo 133 lleva a considerar en un tercer lugar al derecho federal y al local en una misma jerarquía en virtud de lo dispuesto en el artículo 124 de la Ley Fundamental, el cual ordena que "Las facultades que no están expresamente concedidas por esta Constitución a los funcionarios federales, se entienden reservadas a los Estados". No se pierde de vista que en su anterior conformación, este Máximo Tribunal había adoptado una posición diversa en la tesis P.C/92, publicada en la Gaceta del Semanario Judicial de la Federación, Número 60, correspondiente a diciembre de 1992, página 27, de rubro: "LEYES FEDERALES Y TRATADOS INTERNACIONALES. TIENEN LA MISMA JERARQUÍA NORMATIVA", sin embargo, este Tribunal Pleno considera oportuno abandonar tal criterio y asumir el que considera la jerarquía superior de los tratados incluso frente al derecho federal.

Amparo en revisión 1475/98. Sindicato Nacional de Controladores de Tránsito Aéreo. 11 de mayo de 1999. Unanimidad de diez votos. Ausente: José Vicente Aguinaco Alemán. Ponente: Humberto Román Palacios. Secretario: Antonio Espinoza Rangel. El Tribunal Pleno, en su sesión privada celebrada el veintiocho de octubre en curso, aprobó, con el número LXXVII/1999, la tesis aislada que antecede; y determinó que la votación es idónea para integrar tesis jurisprudencial. México, Distrito Federal, a veintiocho de octubre de mil novecientos noventa y nueve. Nota: Esta tesis abandona el criterio sustentado en la tesis P.C/92, publicada en la Gaceta del Semanario Judicial de la Federación Número 60, Octava Epoca, diciembre de 1992, página 27, de rubro: "LEYES FEDERALES Y TRATADOS INTERNACIONALES. TIENEN LA MISMA JERARQUÍA NORMATIVA”.

\section{LA LEY AGRARIA}

La Ley Agraria inició su vigencia el 27 de febrero de 1992, es resultado directo de la reforma al artículo 27 constitucional. Esta ley es de corte neoliberal ya que no recoge el sentir de los campesinos mexicanos y permite que extranjeros participen en las sociedades comerciales propietarias de tierras.

En su título sexto, este ordenamiento legal prevé la posibilidad de que sociedades civiles o mercantiles sean propietarias de tierras agrícolas, ganaderas o forestales. A continuación, citaré literalmente algunas de las disposiciones jurídicas relativas al caso. 
Artículo 126. Las sociedades mercantiles o civiles no podrán tener en propiedad tierras agrícolas, ganaderas o forestales en mayor extensión que la equivalente a veinticinco veces los límites de la pequeña propiedad individual y deberán cumplir con los siguientes requisitos:

I. Deberán participar en la sociedad, por lo menos, tantos individuos como veces rebasen las tierras de la sociedad de los límites de la pequeña propiedad individual. Al efecto, se tomará en cuenta la participación de cada individuo, ya sea directamente o a través de otra sociedad;

II. Su objeto social deberá limitarse a la producción, transformación o comercialización de productos agrícolas, ganaderos o forestales y a los demás actos accesorios necesarios para el cumplimiento de dicho objeto;

III. Su capital social deberá distinguir una serie especial de acciones o partes sociales identificada con la letra $\mathrm{T}$, la que será equivalente al capital aportado de tierras agrícolas, ganaderas o forestales o al destinado a la adquisición de las mismas, de acuerdo con el valor de las tierras al momento de su aportación o adquisición.

Artículo 130. En las sociedades a que se refiere este título, los extranjeros no podrán tener una participación que exceda del $49 \%$ de las acciones o partes sociales de serie $T$.

\section{SOCIEDADES COMERCIALES PROPIETARIAS DE TIERRAS}

Con motivo de esta investigación jurídica, y con el propósito de contar con datos que nos permitan conocer la situación de sociedades civiles y mercantiles propietarias de tierras, fue necesario consultar el correo electrónico del Registro Agrario Nacional, ${ }^{21}$ e incluso entrevistar al director general del Registro, ${ }^{22}$ quien después de explicarle el propósito del trabajo y el uso que se le daría a los datos, me proporcionó ${ }^{23}$ la relación de sociedades comerciales propietarias de tierras agrícolas, ganaderas, o forestales, emisoras de acciones o partes sociales serie " $\mathrm{T}$ ", inscritas en esa institución en el periodo del 7 de enero de 1992 al 30 de abril del 2001. 


\begin{tabular}{|c|c|c|c|}
\hline $\begin{array}{c}\text { NÚM. } \\
\text { DE } \\
\text { PROG. }\end{array}$ & $\begin{array}{l}\text { DENOMINACIÓN O RAZÓN } \\
\text { SOCIAL }\end{array}$ & ESTADO & $\begin{array}{c}\text { SUPERFICIE } \\
\text { DE } \\
\text { TIERRAS }\end{array}$ \\
\hline 1 & San Antonio de Triana, S. A. de C. V. & Zacatecas & $\begin{array}{l}10,000-00-00 \\
\text { Has. }\end{array}$ \\
\hline 2 & Agroindustrial Sonora, S. A. de C. V. & Sonora & $\begin{array}{l}2,348-10-03 \\
\text { Has. }\end{array}$ \\
\hline 3 & Ganadera Dolores, S. A. de C. V. & Nuevo León & 560-46-59 Has. \\
\hline 4 & La Soledad de Triana, S. A. de C. V. & Zacatecas & $\begin{array}{l}6,985-65-80 \\
\text { Has. }\end{array}$ \\
\hline 5 & Agros, S. A. de C. V. & Distrito Federal & 60-00-00 Has. \\
\hline 6 & Ganadera Santa Cecilia, S. A. de C. V. & Coahuila & $\begin{array}{l}23,094-48-51 \\
\text { Has. } \\
\end{array}$ \\
\hline 7 & Finca del Refugio, S. A. de C. V. & Oaxaca & 140-69-91 Has. \\
\hline 8 & Desarrollos del Batán, S. de R. L & Coahuila & $\begin{array}{l}5,407-26-86 \\
\text { Has. }\end{array}$ \\
\hline 9 & $\begin{array}{l}\text { Sociedad Agropecuaria Sacapulco, S. } \\
\text { A. de C. V. }\end{array}$ & Chiapas & 255-74-80 Has. \\
\hline 10 & Agrocrías S. A. de C. V. & Durango & $\begin{array}{l}2,886-51-29 \\
\text { Has. }\end{array}$ \\
\hline 11 & Cafetalera Tepuzapa, S. A. de C. V. & & 875-31-06 Has. \\
\hline 12 & $\begin{array}{l}\text { Impulsora de Desarrollo Citrícula, } \\
\text { S. A. de C. V. }\end{array}$ & Nuevo León & $\begin{array}{l}3,087-77-83 \\
\text { Has. }\end{array}$ \\
\hline 13 & Mayan's Fruit and Meat, S. A. de C. V. & $\begin{array}{l}\text { Distrito Federal } \\
\text { (antes Yucatán) }\end{array}$ & $\begin{array}{l}1,382-00-00 \\
\text { Has. }\end{array}$ \\
\hline 14 & Agrovica ABC, S. A de C. V. & Baja California & 612-40-69 Has. \\
\hline 15 & Dos Ranchos ,S. de R. L. de C. V. & Baja California & 220-55-73 Has. \\
\hline 17 & Rancho Las Glorias, S. A. de C. V. & Chiapas & 166-77-25 Has. \\
\hline 18 & Malvinas, S. A. de C. V. & Tamaulipas & 507-68-79 Has. \\
\hline 19 & Papagos, S. A. de C. V. & Sonora & $\begin{array}{l}3,823-82-00 \\
\text { Has. }\end{array}$ \\
\hline 20 & $\begin{array}{l}\text { Desarrollo Agropecuario Elga, } \\
\text { S. A. de C. V. }\end{array}$ & Distrito Federal & 79-84-71 Has. \\
\hline
\end{tabular}




\begin{tabular}{|c|c|c|c|}
\hline $\begin{array}{c}\text { NÚM. } \\
\text { DE } \\
\text { PROG. }\end{array}$ & $\begin{array}{l}\text { DENOMINACIÓN O RAZÓN } \\
\text { SOCIAL }\end{array}$ & ESTADO & $\begin{array}{c}\text { SUPERFICIE } \\
\text { DE } \\
\text { TIERRAS }\end{array}$ \\
\hline 21 & $\begin{array}{l}\text { Agrobianoba, S. A. de C. V. } \\
\text { (antes Agrícola Bátiz, S. A. de C. V.) }\end{array}$ & $\begin{array}{l}\text { Nuevo León } \\
\text { (antes Sinaloa) }\end{array}$ & $\begin{array}{l}1,116-85-22 \\
\text { Has. }\end{array}$ \\
\hline 22 & Finca España, S. A. de C.V. & Chiapas & 188-47-70 Has. \\
\hline 23 & $\begin{array}{l}\text { Compañía Ganadera Brungo, } \\
\text { S. A. de C. V. }\end{array}$ & Sonora & 32-01-76 Has \\
\hline 24 & Campañas del Desierto, S. A. de C. V. & Sonora & Sin datos \\
\hline 25 & $\begin{array}{l}\text { Compañía Agropecuaria Roldán, } \\
\text { de S. A. de C. V. }\end{array}$ & Veracruz & 379-50-00 Has. \\
\hline 26 & $\begin{array}{l}\text { Agrícola y Ganadera Internacional, } \\
\text { S. A. de C. V. }\end{array}$ & Nuevo León & 288-62-23 Has. \\
\hline 27 & Oro Verde, S. A. de C. V. & Puebla & Sin datos \\
\hline 28 & La Estacada, S. A. de C.V. & Guanajuato & $\begin{array}{l}\text { 3,312-39-75 } \\
\text { Has. }\end{array}$ \\
\hline 29 & Pinar de Tapalpa, S. A. de C. V. & Jalisco & Sin datos \\
\hline 30 & $\begin{array}{l}\text { Comercializadora Agropecuaria } \\
\text { Sta. Gabriela, S. A. de C. V. }\end{array}$ & Veracruz & 80-99-10 Has. \\
\hline 31 & Cítricos de Tamiahua, S. A. de C. V. & Nuevo León & Sin datos \\
\hline 32 & $\begin{array}{l}\text { Ganadera Las Ánimas de Sonora, } \\
\text { S. A. de C. V. }\end{array}$ & Sonora & $\begin{array}{l}13,087-01-15 \\
\text { HAS }\end{array}$ \\
\hline 33 & $\begin{array}{l}\text { Granjas Carrol de México, } \\
\text { S. de R. L. de C. V. }\end{array}$ & Distrito Federal & 542-49-61 Has. \\
\hline 34 & Emexsil, S. A de C. V. & Chihuahua & $\begin{array}{l}5,672-28-82 \\
\text { Has. }\end{array}$ \\
\hline 35 & Ganadera MSR, S. R. L. de C. V. & Sonora & $\begin{array}{l}\text { 2,698-37-64 } \\
\text { Has. }\end{array}$ \\
\hline 36 & Café Santa Teresa, S. A. de C. V. & Chiapas & Sin datos \\
\hline 37 & $\begin{array}{l}\text { Impulsora Agropecuaria La Unión, } \\
\text { S. A. de C. V. }\end{array}$ & Chiapas & 269-32-45 Has. \\
\hline 38 & Brun Agriculture, S. A. de C. V. & Colima & Sin datos \\
\hline 39 & Zaac, S. A. de C. V. & Guanajuato & 980-87-34 Has. \\
\hline
\end{tabular}




\begin{tabular}{|c|l|l|l|}
\hline $\begin{array}{c}\text { NÚM. } \\
\text { DE } \\
\text { PROG. }\end{array}$ & \multicolumn{1}{|c|}{$\begin{array}{c}\text { DENOMINACIÓN O RAZÓN } \\
\text { SOCIAL }\end{array}$} & \multicolumn{1}{|c|}{ ESTADO } & \multicolumn{1}{c|}{$\begin{array}{c}\text { SUPERFICIE } \\
\text { DE } \\
\text { TIERRAS }\end{array}$} \\
\hline 40 & Agromod, S. A. de C. V. & Nuevo León & 351-67-87 Has. \\
\hline 41 & Inagro Jiménez, S. A. de C. V. & Durango & Sin datos \\
\hline 42 & Inagro Gómez Palacio, S. A. de C. V. & Durango & Sin datos \\
\hline 43 & Genetikowi, S. A. de C. V. & Sonora & $152-34-10$ Has. \\
\hline 44 & $\begin{array}{l}\text { Cía.Ganadera El Chaparral, } \\
\text { S. A. de C. V. }\end{array}$ & Chihuahua & Sin datos \\
\hline 45 & Mier Landeros, S. C. & Guanajuato & Sin datos \\
\hline 46 & Agropecuaria La Primavera & Campeche & $150-00-00$ Has. \\
\hline 47 & García Suárez Hermanos, S. A. de C. V. & Guanajuato & $155-53-85$ Has. \\
\hline 48 & Mar Bran, S. A. de C. V. & Guanajuato & $100-29-91$ Has. \\
\hline 49 & Acuícola Clej, S. A de C. V. & Sonora & Sin datos \\
\hline 50 & Total & & $\begin{array}{l}92,054-20-38.72 \\
\text { Has. }\end{array}$ \\
\hline
\end{tabular}

También me proporcionó la relación de sociedades propietarias de tierras en donde participan extranjeros tenedores de acciones o partes sociales series " $\mathrm{T}$ ”, como a continuación se indica:

\begin{tabular}{|c|c|c|c|c|}
\hline $\begin{array}{c}\text { NÚM. } \\
\text { DE } \\
\text { PROG. }\end{array}$ & $\begin{array}{c}\text { SOCIEDAD } \\
\text { PROPIETARIA } \\
\text { DE TIERRAS }\end{array}$ & $\begin{array}{c}\text { TENEDORES } \\
\text { DE ACCIONES } \\
\text { Y/O PARTES } \\
\text { SOCIALES “T” }\end{array}$ & NACIONALIDAD & $\begin{array}{c}\% \mathrm{DE} \\
\text { PARTICIPAC } \\
\text { IÓN }\end{array}$ \\
\hline \multirow[t]{2}{*}{1} & \multirow{2}{*}{$\begin{array}{l}\text { Agroindustrial } \\
\text { Sonora, S. A de C. V. } \\
\text { (Sonora) }\end{array}$} & Persona física & Española & .067 \\
\hline & & Persona física & Española & .010 \\
\hline \multirow[t]{3}{*}{2} & \multirow{3}{*}{$\begin{array}{l}\text { Dos Ranchos, S. de R. } \\
\text { L de C. V. (Baja } \\
\text { California) }\end{array}$} & Persona física & Estadounidense & 16.33 \\
\hline & & Persona física & Estadounidense & 16.33 \\
\hline & & Persona física & Estadounidense & 16.33 \\
\hline 3 & $\begin{array}{l}\text { Agrobianoba, S. A. } \\
\text { de C. V.(Nuevo León) }\end{array}$ & Persona moral & Estadounidense & 49 \\
\hline
\end{tabular}




\begin{tabular}{|c|l|l|l|c|}
\hline 4 & $\begin{array}{l}\text { Granjas Carroll de } \\
\text { México, S. de R. L. de } \\
\text { C. V. (D. F.) }\end{array}$ & Persona moral & Estadounidense & 49 \\
\hline 5 & $\begin{array}{l}\text { Genetikowi, S. A. de } \\
\text { C. V. (Sonora) }\end{array}$ & Persona moral & Canadiense & 49 \\
\hline 6 & $\begin{array}{l}\text { Mar Bran, S. A. de C. } \\
\text { V. (Guanajuato) }\end{array}$ & Persona moral & Estadounidense & 25 \\
\hline
\end{tabular}

\section{El CENTRo INTERNACIONAL DE ARREGLO DE DIFERENCIAS RELATIVAS A INVERSIONES (CIADI)}

Respecto al CIADI —en inglés: ICSID (The International Centre for the Settlement of Investment Disputes)— se indagó lo siguiente:

En 1965 se creó este centro bajo los auspicios del Banco Internacional para la Reconstrucción y el Desarrollo, conocido simplemente como Banco Mundial, con la finalidad de proporcionar servicios de mediación y principalmente de arbitraje a las disputas surgidas entre gobiernos (estados soberanos) e inversionistas extranjeros. El CIADI, mejor conocido por sus siglas en inglés ICSID, fue el resultado de la Convención Internacional sobre Solución de Controversias entre Estados y los Nacionales de Otros Estados, que ha sido firmada por más de 139 Estados (Al 13 de abril del 2001, son 148 estados contratantes y signatarios del convenio, de los cuales 134 han depositado sus instrumentos de ratificación. http://www.wordbank.org/icsid.). Aunque es una organización internacional totalmente autónoma, tiene lazos muy estrechos con el Banco Mundial y con el Organismo Multilateral de Garantía de Inversiones (mejor conocido por su acrónimo en inglés MIGA -Multilateral Investment Guarantee Agency- (Citado por Rodríguez González-Valadez, Carlos, op. cit., nota 15, p. 190. El MIGA se creó igualmente bajo los auspicios del Banco Mundial en Seúl en 1985, entrando en vigor el 12 de abril de 1988. Es un organismo multilateral formado por países ratificadores y suscriptores de sus acciones. La suscripción está dividida en dos categorías, la primera por los países en vías de desarrollo y Suiza. La MIGA es un organismo que tiene personalidad propia y que actúa como subrogante de un inversionista que recibió el pago del seguro. El anexo II del Convenio Constitutivo de la MIGA prevé la negociación y la conciliación como métodos previos al arreglo y, en caso de no lograrse, se acudirá al arbitraje cuyo Tribunal se integrará y actuará de conformidad con las reglas del ICSID. Es decir, la MIGA utiliza el arbitraje para solucionar conflictos de estados entre sí derivados de controversias de naturaleza pri- 
vada) cuyo propósito es fomentar el flujo de inversiones para y entre los países en desarrollo emitiendo garantías para riesgos no comerciales. ${ }^{24}$

\section{Jurisdicción y competencia del CIADI}

\section{Ámbito material}

a. Controversias jurídicas en materia de inversiones

En virtud del Convenio de Washington, los órganos de solución de controversias del CIADI sólo son competentes para resolver controversias jurídicas en materia de inversiones. ${ }^{25}$

La jurisdicción del Centro se extenderá a las diferencias de naturaleza jurídica que surjan directamente de la inversión. ${ }^{26}$

Para que se dé una inversión en sentido económico es necesario que exista, en primer lugar, una aportación económica de moneda o de bienes, que pueda ser materiales o inmateriales, tales como derechos de propiedad industrial o intelectual. En segundo lugar, tal aportación debe realizarse a medio o largo plazo (3 o 7 años) y, en tercer lugar, la operación económica debe comportar un riesgo, en el sentido de que la remuneración buscada por el inversor — que siempre tiene un interés lucrativo— dependa de las ganancias o las pérdidas de la empresa. ${ }^{27}$

La voluntad de las partes para definir una controversia jurídica como derivada directamente de una inversión está limitada por la exclusión de las controversias comerciales del ámbito material de competencia del CIADI. ${ }^{28}$

Corresponde al secretario general del CIADI denegar el registro de una solicitud de conciliación o arbitraje así entendida. ${ }^{29}$

México y Canadá no han firmado el Convenio de Washington, por tanto no son estados contratantes y signatarios del CIADI, según información obtenida de la consulta a Internet, el 03 de mayo de este año. ${ }^{30}$

24 Idem.

25 Vives Chillida, Julio A., El Centro Internacional de Arreglo de Diferencias Relativas a Inversiones (CIADI), España, McGraw-Hill, 1998, pp. 88 y 89.

26 Artículo 25.1 del Convenio de Washington, de 18 de marzo de 1965.

27 Sobre la noción de inversión, véase a Carreau, D. et al., Droit International Economique, 3 a. ed., París, LGDJ, 1990, pp. 558-578. Citado por Vives Chillida, Julio A., op. cit., nota 25, p. 93.

28 Vives Chillida, Julio A., op. cit., nota 25, p. 96.

29 Véase Doc. CIADI/5Rev. 1, de 17 de julio de 1981.

30 http://www.wordbank.org/icsid. 
Sin embargo, nuestro país ha sido demandado ante el CIADI por inversionistas extranjeros, particularmente de Estados Unidos de América, por incumplimiento, según ellos, a disposiciones contenidas en el capítulo XI del TLCAN.

A continuación cito la relación de casos iniciados en contra del gobierno de México, al amparo del capítulo XI, sección B, del TLCAN, proporcionada por la Dirección General de Consultoría Jurídica de Negociaciones, de la Subsecretaría de Negociaciones Comerciales Internacionales, de la Secretaría de Economía. ${ }^{31}$

1. Laudo Definitivo de 6 de octubre de 1999, iniciado por Robert Azinian, Kenneth Davitian y Ellen Baca. Caso CIADI No. ARB (AF)/97/2.

En este caso, a los demandantes se les había otorgado una concesión para recolección y eliminación de basura en el municipio de Naucalpan de Juárez, Estado de México, mismo que fue dejado sin efecto por el propio Ayuntamiento Municipal, en virtud de que los demandantes no cumplieron con las obligaciones contraídas en dicho acto de concesión. Primero, se demandó la nulidad de la anulación de la resolución del Ayuntamiento, ante el Tribunal de lo Contencioso Administrativo. Al no obtener resultados favorables, los demandantes promovieron amparo directo ante el Tribunal Colegiado de Circuito, que fue negado, y posteriormente promovieron el Arbitraje ante el CIADI. Constituido el tribunal arbitral, por resolución de 6 de octubre de 1999, se dio la razón al gobierno de México.

2. Laudo definitivo de 2 de junio de 2000 , iniciado por la empresa estadounidense Waste Management Inc., en representación de Acaverde S. A. de C. V., Caso CIADI No. ARB (AF)/98/2.

En este caso, el gobierno mexicano fue absuelto por cuanto a la indemnización de daños y perjuicios reclamados en su contra; y al contrario se condenó a la parte demandante al pago de las costas del procedimiento arbitral. El problema se presentó en el municipio de Acapulco, Estado de Guerrero, esto con el motivo del título de concesión para el establecimiento de un relleno sanitario.

3. Laudo arbitral de 30 de agosto de 2000, iniciado por la empresa estadounidense Metalclad Corporation. Caso CIADI No. ARB (AF)97/1.

En este caso, el gobierno de México fue demandado por Metalclad, empresa de confinamiento técnico de residuos industriales, que operó en 
el municipio de Guadálcazar, Estado de San Luis Potosí. En el laudo arbitral, México fue condenado al pago de 16,685,000.00 de dólares en favor de la empresa demandante

El gobierno de México impugnó el laudo arbitral que antecede ante la Suprema Corte de la provincia Canadiense de Colombia Británica, autoridad internacional que en una segunda resolución modificó relativamente el laudo arbitral impugnado, y el gobierno de México fue condenado al pago de 15,000,000.00 de dólares en favor de la empresa demandante.

\section{b. Ámbito personal}

En este apartado resalta la importancia de conocer el contenido y alcances de las cláusulas de trato nacional y de nación más favorecida, previstas en los artículos 1102 y 1103 del capítulo XI del TLCAN.

\section{-El estado contratante}

Estados Unidos Mexicanos se convierte en Estado contratante a partir de que recibe o es huésped de la inversión extranjera, y más particularmente, a partir de que permite que extranjeros participen como socios en sociedades civiles o mercantiles propietarias de tierras agrícolas, ganaderas o forestales.

Para los propósitos del capítulo XI del TLCAN, los Estados contratantes en materia de inversión, también serán Estados Unidos de América y Canadá.

\section{—Las personas físicas}

El mexicano por nacimiento o por naturalización que invierta en otro Estado que no sea los Estados Unidos Mexicanos, será la persona física a quien se denominará inversor o inversionista. Y para el caso de extranjeros, es la persona física que invierta en los Estados Unidos Mexicanos.

En el apartado 2, Letra a) del artículo 21 del Convenio, dice lo que ha de entenderse como "nacional de otro Estado Contratante" en cuanto a las personas físicas:

Toda persona natural que tenga, en la fecha en que las partes consintieron someter la diferencia a conciliación o arbitraje y en la fecha en que fue registrada la solicitud prevista en el apartado (3) del artículo 28, o en el 
apartado (3) del artículo 36, la nacionalidad de un Estado Contratante distinto del Estado parte en la diferencia; pero en ningún caso comprenderá las personas que, en cualquiera de ambas fechas, también tenían la nacionalidad del Estado parte en la diferencia. ${ }^{32}$

Los inversionistas de los Estados Parte podrán someter su demanda a arbitraje a nombre propio o bien a nombre de la empresa de la cual son inversionistas y que controlen directa o indirectamente, por violaciones a las disposiciones del capítulo de inversión, o bien por violación al artículo 1502, párrafo 3, inciso a) (monopolios y empresas de Estado), y al artícu-lo 1503, inciso 2 (empresas de Estado), cuando dichas violaciones estén vinculadas con el capítulo de inversiones. Dichas violaciones deberán ocasionar una pérdida o daño. ${ }^{33}$

\section{—Las personas jurídicas}

La nacionalidad, como atributo de la persona jurídica, es el criterio para determinar la legitimidad de las personas jurídicas en este tipo de controversias, en el marco del derecho internacional privado.

En México, por ejemplo, las sociedades civiles o mercantiles constituidas al amparo de nuestra legislación, son personas jurídicas de nacionalidad mexicana.

Aquí la importancia estriba en tener claro que si un extranjero participa como tenedor de acciones o partes sociales serie " $\mathrm{T}$ ", en una sociedad civil o mercantil propietaria de tierras, y de presentarse una controversia, al considerar que su inversión ha sufrido daño o pérdida, pueda demandar al Estado mexicano ante el CIADI, pero como persona física, como inversionista en lo individual, pero no podrá demandar como persona jurídica, o sea, no podrá demandar como sociedad civil o mercantil, ya que la sociedad en sí no es inversionista, pues también se constituye por inversionistas mexicanos, que se entiende, son titulares del $51 \%$ de las acciones.

"También se aclara que sólo las personas físicas y morales mexicanas podrán ser propietarias de la tierra destinada a propósitos agrícolas, ganaderos o silvícolas, y que únicamente podrán ser inversionistas de los Estados Parte adquirir las acciones de la serie " $T$ ", hasta un 49\%". 34 


\section{EL ARBITRAJE COMO MECANISMO DE SOLUCIÓN DE CONTROVERSIAS}

Es conveniente establecer ciertas precisiones terminológicas en el contexto de esta materia; es decir, deben advertirse las semejanzas que existen en los distintos tipos de arbitraje y hacer énfasis en las divergencias entre arbitraje de derecho privado y arbitraje de derecho público; entre arbitraje interno y arbitraje internacional; entre arbitraje comercial y arbitraje civil.

El arbitraje de derecho internacional público tiene por objeto el arreglo de los litigios entre los Estados como entidades soberanas, mediante árbitros designados libremente y sobre la base del respeto a las instituciones jurídicas. El arbitraje privado, en cambio, trata de resolver las controversias suscitadas entre particulares y si bien es cierto que los Estados, algunas veces actúan en el comercio sin la investidura de soberanía, participando activamente a través de corporaciones o empresas denominadas por los intereses del sector público, también lo es que en tales circunstancias los diferendos que se susciten con otras empresas de esta naturaleza o con particulares, ya no inciden en la jurisdicción del derecho internacional público, pudiendo ser resueltos a través del arbitraje privado.

Es igualmente útil depurar la nomenclatura en lo que respecta al carácter interno e internacional del arbitraje. La problemática del primero se plantea dentro de un sistema jurídico único. El segundo surge cuando existe un elemento extraño, ajeno al carácter local de la controversia; es decir, cuando una de las partes contratantes es extranjera o cuando los efectos del convenio se producen en el exterior; en fin, cuando surge cualquier conexión con otra legislación distinta a la interna. En estos casos estamos en presencia del arbitraje internacional como instrumento idóneo para eludir los problemas inherentes a la confrontación del derecho extraño, incluyendo la sumisión a tribunales foráneos. ${ }^{35}$

\section{El arbitraje comercial internacional}

El arbitraje es un método por el cual las partes en una disputa convienen en someter sus diferencias a un tercero, o a un tribunal constituido especialmente para tal fin, con el objeto de que sea resuelto conforme a las normas que las partes especifiquen, usualmente normas de derecho internacional, y con el entendimiento que la decisión ha de ser aceptada por los contendientes como arreglo final.

35 Siqueiros, José Luis, El arbitraje en los negocios internacionales de naturaleza privada, México, Escuela Libre de Derecho, Fondo para la Difusión del Derecho, 1992, pp. 9 y 10. 
Consiste, pues, el arbitraje, en el ajuste de las controversias internacionales, por métodos y reglas legales, por árbitros escogidos por las partes contendientes. Se diferencia de la mediación, en que el árbitro debe pronunciar una resolución en una cuestión de derecho, en tanto que, el mediador propone un compromiso, o recomienda lo que mejor se debe hacer, no lo más justo. ${ }^{36}$

El arbitraje es una vía, es un mecanismo de solución de controversias comerciales internacionales al que puede recurrir un inversionista extranjero tenedor de acciones o partes sociales de serie " $\mathrm{T}$ " en sociedades civiles o mercantiles propietarias de tierras agrícolas, ganaderas o forestales, cuando considere que su inversión ha sufrido daño o pérdida por incumplimiento a una de las obligaciones pactadas por parte de México como Estado huésped o receptor de la inversión.

Las experiencias que ha tenido nuestro país en el arbitraje internacional no han sido muy satisfactorias. Los ejemplos abundan. El primer caso, llevado a la Corte Permanente de Arbitraje en 1902, pasando por la pérdida de la Isla de la Pasión o Clipperton a favor de Francia, en 1931, debido al laudo arbitral emitido por el rey Víctor Manuel, de Italia; el caso de El Chamizal, cuyo laudo no fue atacado por Estados Unidos de América durante decenas de años, y los Tratados de Bucareli en 1923. Para evitar estos arbitrajes que dejan en manos de una persona o institución la absoluta libertad de decisión, la comunidad internacional ha perfeccionado los mecanismos de solución. Un ejemplo de éstos, es la Ley General de Tratados, misma que en el artículo octavo establece los principios que debe tener todo convenio de solución de controversias, del cual México sea parte y que son:

1. Igualdad de mexicanos y extranjeros, con base en el principio de reciprocidad internacional.

2. Que se asegure la garantía de audiencia y el debido ejercicio de las defensas de los interesados.

3. Imparcialidad de los órganos de decisión. ${ }^{37}$

\section{El procedimiento arbitral}

Previo a iniciar el procedimiento de arbitraje, el inversionista deberá aceptar las normas del apartado B, del capítulo XI, del TLCAN, y renunciar a

36 Sepúlveda, César, Derecho internacional, 17a. ed. actualizada, México, Porrúa, 1996, pp. 395 y 396.

37 Serrano Migallón, Fernando, op. cit., nota 9, p. 71. 
iniciar o continuar los recursos de derecho que establezca el derecho positivo del país huésped de la inversión, con excepción de que sí podrá solicitar medidas precautorias que permitan garantizar la reparación del posible daño o pérdida a su inversión.

La renuncia que antecede deberá manifestarse por escrito y deberá entregarse al Estado Parte contra el cual se presenta la demanda, y deberá incluirse en la solicitud de arbitraje.

Un requisito indispensable para iniciar el procedimiento arbitral es el consentimiento establecido en una cláusula del CIADI, y contenido en el Convenio de Washington. ${ }^{38}$

Antes de que un inversionista extranjero presente una demanda en contra del gobierno mexicano ante el CIADI, podrá promover consultas y negociaciones. Al no tener éxito, en el término de 90 días, el inversionista deberá notificar al gobierno mexicano su intención de acudir al procedimiento arbitral ante el CIADI. El cómputo de 90 días se cuenta a partir de manera retroactiva a la fecha de presentación de la demanda. En la notificación el inversionista deberá especificar su nombre y dirección, las disposiciones que según han sido violadas, los hechos base de su reclamación y una aproximación de la cantidad que se reclama por daños.

$\mathrm{El}$ inversionista tiene un término de seis meses, contados a partir del surgimiento de los hechos que motivaren la demanda, para acudir al procedimiento arbitral. En este caso, el inversionista puede optar entre las normas del CIADI, o bien, podrá acudir a las Reglas del Mecanismo Complementario del CIADI, o por último, puede recurrir a la regla de arbitraje de la Comisión de Naciones Unidas sobre Derecho Mercantil Internacional (CNUDMI), en inglés Uncitral (United Nations Commission on Internacional Trade Law).

En este apartado cabe recordar que México no forma parte del CIADI, por lo que en caso de que sea demandado, se aplicarán las Reglas del Mecanismo Complementario de ese centro.

\section{El consentimiento}

La participación de los particulares en los procedimientos ante el CIADI es el punto de partida del esquema de presentación del consentimiento a los medios de solución de controversias contenidos en el Convenio de Washington. En este esquema, los pilares básicos son, en primer lugar, que el fundamento de la 
competencia de las comisiones de conciliación y tribunales del CIADI es el consentimiento de las partes en la diferencia: El Estado contratante y el nacional de otro Estado Contratante y, en segundo lugar, que la participación de los Estados en el Convenio no supone, por sí sola, la obligación de someter ninguna controversia al CIADI para lo cual se requiere un consentimiento adicional o acuerdo con el nacional de otro Estado Contratante al efecto. ${ }^{39}$

"El consentimiento debe otorgarse en forma escrita". 40 "El consentimiento deberá de manifestarse al momento en que se presenta la solicitud al Centro". ${ }^{41}$ "El consentimiento de un Estado a someter una controversia al CIADI con una empresa extranjera es vinculante e irrevocable". ${ }^{42}$ "El consentimiento dado por las partes no podrá ser unilateralmente revocado. El consentimiento es la piedra angular en que descansa la jurisdicción del Centro". 43 "El consentimiento irrevocable del Estado no sólo produce efectos respecto del particular, que tiene derecho a recurrir al Centro, sino que implica una obligación internacional, frente a otros Estados Contratantes, de respetar las obligaciones asumidas frente al cocontratante extranjero". 44

En cuanto a los efectos positivos del consentimiento al arbitraje, una vez alterado el régimen general respecto al agotamiento de los recursos internos y la protección diplomática, consisten en el derecho del inversor de litigar directamente en un procedimiento arbitral internacional frente al Estado receptor de la inversión - incluyendo la posibilidad de participar en un procedimiento de anulación - y en el beneficio de poder obtener a su favor un laudo arbitral que es, al mismo tiempo, una sentencia internacional obligatoria para el Estado condenado frente al Estado nacional del inversor si se incumple éste puede presentar una reclamación internacional- y una sentencia interna de todos los Estados contratantes del Convenio. ${ }^{45}$

De igual forma, el consentimiento deberá ser acorde con el capítulo II del CIADI y las Reglas del Mecanismo Complementario, artículo II de la Convención de Nueva York (Convención de Naciones Unidas sobre Reconocimiento y Ejecución de Sentencias Arbitrales Extranjeras) y el capítulo I de la Convención Interamericana sobre el Arbitraje Comercial Internacional. ${ }^{46}$

40 Artículo 25.1 del Convenio de Washington, de fecha 18 de marzo de 1965. 
México y Canadá no son Estados contratantes y signatarios del Convenio de Washington; sin embargo, pueden ser demandados ante el CIADI por algún inversionista de Estados Unidos de América, ya que este país sí forma parte de ese convenio ${ }^{47}$ y del TLCAN. México, también puede ser demandado por un inversionista canadiense, en términos del capítulo XI, apartado B, del TLCAN.

\section{Laudo arbitral}

Existen únicamente dos tipos de resoluciones que un tribunal arbitral puede dictar en contra de un Estado firmante del TLC: a) Pago de daños pecuniarios e intereses; o b) La restitución de la propiedad, o en sustitución, el pago de daños pecuniarios, más intereses.

Asimismo establecen exclusiones a la aplicación del procedimiento arbitral, entre otros, en los siguientes casos: Cuando se involucran aspectos de seguridad nacional, o en las cuestiones que cada estado haya señalado en lo particular en el anexo 1138.2. En el caso particular de México, las decisiones de la CNIE (Comisión Nacional de Inversiones Extranjeras) que resulten de someter a su revisión una inversión para la adquisición o establecimiento en las actividades restringidas señaladas en el anexo 1; asimismo, como para la adquisición de más del $49 \%$ en actividades no restringidas cuando el monto de la inversión sea superior a los umbrales aplicables.

Las excepciones son necesarias, pues la Cláusula Calvo requiere que los inversionistas extranjeros en México se consideren como nacionales con respecto a su inversión y convienen en no invocar la protección de su gobierno en relación con dicha inversión. En consecuencia, únicamente tienen a su alcance los dos recursos que se han mencionado.

No obstante lo anterior, es probable que México modifique sus bases constitucionales y legales que impone la Cláusula Calvo en sus tratados con inversionistas extranjeros, en vista de que por el momento se puede interpretar como un impedimento para someterse al arbitraje para la solución de controversias con inversionistas extranjeros.

Bajo estas circunstancias, es probable que México se vea en la necesidad de modificar su postura frente a instituciones tales como el CIADI, el MIGA y la propia Cláusula Calvo, aceptando el arbitraje internacional como un medio de solución de posibles conflictos, con lo cual se incrementaría notablemente la confianza del inversionista extranjero, y no únicamente del estadounidense y canadiense, para invertir en México. ${ }^{48}$

47 Estados Unidos de América firmó el Convenio de Washington el 27 de agosto de 1965, lo depositó el 10 de junio de 1966, y entró en vigor el 14 de octubre de 1966 (www.wordbank.org/icsid).

48 Witker, Jorge, "Aspectos regulatorios-institucionales de la inversión extranjera directa", 
Es importante mencionar que en el tratamiento de estas controversias, el Tribunal Arbitral se rige por las disposiciones del derecho internacional y del TLCAN. "El modus operandi del tribunal se regirá por las normas que escojan las partes y el derecho aplicable será el TLCAN y el internacional (artículo 1331). Deberá, asimismo, acatar las interpretaciones que la comisión haya formulado sobre alguna disposición del tratado, por lo que cabría equipararla con la jurisprudencia obligatoria". ${ }^{49}$

\section{LOS ACUERDOS DE PROMOCIÓN Y PROTECCIÓN DE INVERSIONES (APRIS)}

Los Apris son tratados internacionales en materia de inversión extranjera, celebrados entre dos Estados, con objeto de promover los flujos de capital y brindar a las inversiones de ambos países seguridad jurídica.

Estos tratados también constituyen un medio eficaz para diversificar el origen de los flujos de la inversión extranjera directa (IED), hacia nuestro país, dando eficacia a la política de apertura y no discriminación en materia de inversión.

Los Apris transmiten un mensaje positivo, competitivo y de seguridad jurídica a los inversionistas de países altamente exportadores de inversión productiva hacia México o con los que se desea incrementar los flujos de IED.

Los Apris incorporan varios principios a través de los cuales se busca proteger a la inversión en el territorio de cualquiera de las partes. Dichos principios son los relativos al trato a la inversión (Trato Nacional y de Nación más favorecida), transferencias, expropiación e indemnización y los mecanismos para la solución de controversias.

México ha celebrado Apris con los siguientes países: nales, 2a. ed., México, UNAM, Instituto de Investigaciones Jurídicas, 2002, pp. 98 y 99.

49 Cruz Miramontes, Rodolfo, El TLC: controversias, soluciones y otros temas conexos, México, McGraw-Hill, 1997, p. 34. 


\begin{tabular}{|l|c|c|}
\hline \multicolumn{1}{|c|}{ PAÍ́s } & FIRMA & $\begin{array}{c}\text { PUBLICACIÓN } \\
\text { EN DOF }\end{array}$ \\
\hline España & $22 / \mathrm{jun} / 95$ & $19 / \mathrm{mar} / 97$ \\
\hline Suiza & $10 / \mathrm{jul} / 95$ & $20 / \mathrm{ago} / 98$ \\
\hline Argentina & $13 / \mathrm{nov} / 96$ & $28 / \mathrm{ago} / 98$ \\
\hline Alemania & $25 / \mathrm{ago} / 98$ & Pendiente \\
\hline Países Bajos & $13 / \mathrm{may} / 98$ & $10 / \mathrm{jul} / 2000$ \\
\hline Austria & $29 / \mathrm{jun} / 98$ & Pendiente \\
\hline Unión & & Pendiente \\
\hline Belgo-Luxemburguesa & $27 / \mathrm{ago} / 98$ & $30 /$ nov/2000 \\
\hline Francia & $12 / \mathrm{nov} / 98$ & $30 /$ nov/2000 \\
\hline Finlandia & $22 / \mathrm{feb} / 99$ & Pendiente \\
\hline Uruguay & $30 / \mathrm{jun} / 99$ & $08 / \mathrm{ene} / 2001$ \\
\hline Portugal & $11 / \mathrm{nov} / 99$ & Pendiente \\
\hline Italia & $24 / \mathrm{nov} / 99$ & $30 /$ nov/2000 \\
\hline Dinamarca & $13 / \mathrm{abr} / 2000$ & $27 /$ jul/2001 \\
\hline Suecia & $03 / \mathrm{oct} / 2000$ & Pendiente \\
\hline Corea del Sur & $14 / \mathrm{nov} / 2000$ & Pendiente \\
\hline Grecia & $30 / \mathrm{nov} / 2000$ & \\
\hline
\end{tabular}

NoTA: Información obtenida en el correo electrónico de la Secretaría de Economía. ${ }^{50}$

50 http://www.economía-snci.gob.mx [http://www.starmedia.com/noticias. 25 de mayo del año 2001. El juez David Taysoe, de la Suprema Corte de Columbia Británica de Canadá, se sustenta sobre la impugnación del fallo de un panel arbitral establecido por el amparo del capítulo 11 del Tratado de Libre Comercio de América del Norte con relación a una disputa entre la empresa Metalclad Corporation y el gobierno de México. La corte canadiense desechó una parte significativa del laudo arbitral. Coincidió con México en que el panel había excedido sus facultades al establecer que los actos del Ayuntamiento de Guadalcázar, San Luis Potosí, y otras autoridades mexicanas, al cancelar la instalación de un confinamiento de residuos tóxicos, eran violatorios del TLCAN. La corte redujo de 16 a 15 millones de dólares la compensación que el panel impuso a México, pero inclinó interferir en la determinación del órgano de arbitraje. En 1997, Metalclad demandó a México por más de 130 millones de dólares en virtud de que no pudo abrir el confinamiento de Guadalcázar. El laudo arbitral fue emitido el 30 de agosto de 2000. El arbitral internacional determinó que México había violado sus obligaciones establecidas en el capítulo 11 del TLCAN, al adoptar medidas equivalentes a una expropiación. México hizo uso de la facultad que le confiere el propio TLCAN para impugnar laudos arbitrales. Presentó un recurso ante la Corte de Columbia Británica, por haber sido esa provincia canadiense la sede del panel arbitral. La Secretaría de Economía está analizando la sentencia de la corte canadiense para determinar los siguientes pasos a tomar]. 
En relación a los Apris, no se han presentado controversias en contra de México ante el CIADI, al menos en el correo electrónico ${ }^{51}$ no existe información al respecto. De acuerdo con Julio A. Vives Chillida, lo aconsejable es que en los Apris se deben contener indicaciones más precisas en la definición de inversión, y cita el caso de México y España. ${ }^{52}$

\section{El CASO PUNTA BANDA}

En 1973, se dotó de tierras al poblado Coronel Esteban Cantú, municipio de Ensenada, Baja California. La empresa de particulares denominada Purua, Punta Banda, se inconformó en contra de esa resolución presidencial y de su ejecución, que se había efectuado en 1987, argumentando que una superficie de 18-00-00 hectáreas no fueron afectadas y que indebidamente se entregaron al núcleo agrario.

Después de años de litigios, los particulares obtuvieron el amparo y protección de la justicia federal, del que se derivó el incidente de inejecución 163/97. Durante ese tiempo, los ejidatarios del poblado, por medio de contratos (fideicomisos), permitieron que extranjeros, particularmente estadounidenses, se establecieran en esos terrenos, incluso se construyeron casas-habitación, centros de esparcimiento y deportivos, hoteles, etcétera, aproximadamente 60 familias de estadounidenses establecieron sus residencias en esos terrenos.

Vale la pena señalar que en Baja California, el $80 \%$ de los poblados ejidales tienen vista al mar y sus tierras se encuentran en poder de extranjeros, esto a partir del sexenio de Luis Echeverría Álvarez, a la fecha.

La empresa Purua Punta Banda solicitó a la Suprema Corte de Justicia de la Nación, la ejecución de su resolución, a lo que se oponían los propios ejidatarios del poblado y los estadounidenses que ocupaban esos terrenos; sin embargo, el 30 de octubre del 2000, elementos de la Policía Federal Preventiva prestaron auxilio a la Secretaría de la Reforma Agraria y se procedió a la ejecución de la resolución, con el desalojo respectivo. De esa manera, las familias estadounidenses ahí asentadas fueron"víctimas" de la disputa de tierras sostenida por el grupo Purua, Punta Banda y los ejidatarios del poblado Coronel Esteban Cantú.

52 http://www.economía-snci.gob.mx. Los Estados Unidos Mexicanos y el Reino de España firmaron un Acuerdo para la Promoción y Protección Recíproca de Inversiones, el 22 de junio de 1995, y se publicó en el Diario Oficial de la Federación el 19 de marzo de 1997. 
Como consecuencia del cumplimiento a la resolución de la Suprema Corte de Justicia de la Nación, Dennis Payton, representante jurídico de los estadounidenses, anunció que presentaría demanda en contra del gobierno mexicano por el pago de daños equivalente a 75,000,000.00 de dólares $(50,000,000.00$ en construcción de residencias).

Punta Banda — donde un conflicto por la posesión de la tierra se acaba de resolver con el desalojo de varias decenas de estadounidenses- es prototipo de lo que ocurre a lo largo de 140 kilómetros de costa entre Tijuana y Ensenada: especulación con los terrenos, disputas por la tenencia de la tierra, sacrificio de los ejidos en aras del turismo, contaminación y eliminación de las formas locales de subsistencia.

La neurosis turística invade toda la Península de Baja California y propicia una furiosa competencia por vender terrenos atractivos para los estadounidenses a precios ridículos. ${ }^{53}$

Por razones naturales la mayor parte de las tierras ejidales con dominio pleno en Baja California han sido comercializadas, dijo Eduardo Robledo, el anterior Secretario de la Reforma Agraria, en su última visita a Baja California Sur.

Orondo presumió que la inmobiliaria ejidal más importante del país está en Los Cabos, y constituye un ejemplo nacional. Para desarrollar otros ejidos, afirmó, la secretaría debe continuar capacitando y asesorando a sus beneficiarios para potencializar la plusvalía de sus predios. Lo que no contó el secretario es la historia de los abusos cometidos en el ejido San José del Cabo, donde se fundó la inmobiliaria ejidal a la que se refirió.

María Luisa Cabral, investigadora de relaciones internacionales en la Universidad Autónoma de Baja California Sur, afirma que 23\% de los fideicomisos del país están en este estado, y que la península concentra más de la mitad del total en el país. En Baja California, los pequeños propietarios malbaratan sus terrenos que las empresas de bienes raíces venden, quintuplicando su inversión. En la entidad hay más de 60 empresas de bienes raíces, filiales de estadounidenses, comenta la autora de $L a$ soberanía y el fideicomiso de inmuebles para extranjeros en Baja Cali-

53 Scherer Ibarra, María, "Land for sale... Baja: la invasión del norte”, Proceso, México, núm. 1258, 10 de diciembre de 2000, p. 44. 
fornia Sur. Calcula que 20\% de las costas de la península está ocupado por fideicomisos.

Esta figura, señala, es aprobada de manera discrecional por las dependencias federales, y aumenta las facilidades que brinda a los extranjeros. Prueba de ello es la última modificación a la Ley de Inversión Extranjera, durante el gobierno de Carlos Salinas, cuando se extendió el plazo de disfrute de las tierras de 30 a 50 años.

"Nadie tiene una idea cierta de cuántos terrenos están en manos de extranjeros, porque adquieren los fideicomisos en su calidad de turistas y se pierde el control", explica. Es sarcástico, reflexiona Cabral, que los ejidos en Baja California nacieron "para acabar con los derechos vigentes de compañías estadounidenses, y no por una necesidad campesina de tierra", cuando actualmente miles de hectáreas están, otra vez, ocupadas por extranjeros.

María Luisa Cabral concluye: "Ojalá todo acabara con el fideicomiso. Basta con tener domicilio en México para que una empresa de bienes raíces se considere nacional y pueda comprar lo que sea. No necesita más". ${ }^{54}$

Al investigar lo sucedido en Punta Banda, que como se puede advertir, es un asunto que se derivó precisamente de la tenencia de la tierra; la Subsecretaría de Negociaciones Comerciales, de la Secretaría de Economía, a través de la Dirección General de Consultoría Jurídica de Negociaciones, ${ }^{55}$ me proporcionó copia del aviso de intención de presentar una demanda de arbitraje, conforme a la sección B, capítulo XI, del TLCAN, en contra del gobierno mexicano. Este aviso se presentó el 10 de noviembre de 2000, por Dennis John Peyton, en representación de los extranjeros que fueron desalojados el 30 de octubre de ese mismo año

Los inconformes sostienen que el gobierno de México violó las obligaciones contenidas en los artículos 1102, 1105 y 1110, del TLCAN, que se refieren a trato nacional, estándar mínimo de trato, y expropiación y compensación. Los extranjeros buscan un desagravio y pretenden el pago de daños por no menos de 75 millones de dólares, los costos relacionados con los procesos, honorarios y gastos con respecto a las acciones legales, además del pago de intereses previos y posteriores al fallo, que en su caso fije el tribunal arbitral, además de las consecuencias fiscales y de otro desagravio que el asesor jurídico pudiera recomendar. 
Este aviso de intención fue notificado a la Secretaría de Comercio y Fomento Industrial (hoy Secretaría de Economía), a los departamentos de Estado y de Comercio, a la Oficina de Asuntos Interamericanos y del TLCAN, y de igual forma a la Embajada de Estados Unidos en México.

Como resultado de esta investigación, se me informó por la Dirección de Consultoría Jurídica de la Secretaría de Economía, que este asunto se encuentra en la etapa de consultas.

No sólo en la península de Baja California se presentan problemas derivados de la tenencia de la tierra en donde participan extranjeros, en los estados de Guerrero, Sonora, Sinaloa y Nayarit, entre otros, empiezan a surgir conflictos, en donde no únicamente participan mexicanos en contra de extranjeros, ${ }^{56}$ sino de extranjeros contra extranjeros..$^{57}$

\section{CONCLUSIONES}

Primera. Con la reforma al artículo 27 constitucional de 6 de enero de 1992, se abrió la posibilidad constitucional y legal para que extranjeros puedan participar hasta en un $49 \%$ en acciones o partes sociales de serie " $T$ ", en sociedades civiles o mercantiles propietarias de tierras agrícolas, ganaderas o forestales, en nuestro país, ya que anteriormente el propio precepto constitucional prohibía que las sociedades adquirieran en propiedad tierras.

Segunda. Al entrar en vigor el Tratado del Libre Comercio de América del Norte (TLCAN) el 1 de enero de 1994, existe la posibilidad de que extranjeros que participen en sociedades comerciales propietarias de tierras, al considerar que sufren daño o pérdida en sus inversiones con motivo de incumplimiento por parte del gobierno mexicano como Estado huésped de la inversión, respecto de las obligaciones que señala el capítulo XI del TLCAN, puedan demandar al gobierno mexicano ante tribunales establecidos con motivo de dicho tratado y ante la OMC (Organización Mundial del Comercio), cuando se presuma incumplimiento a obligaciones establecidas en Apris.

56 Expediente 1145/2000, radicado en el Tribunal Unitario Agrario Distrito 28, en Hermosillo, Sonora. El 30 de abril de 2002, resolví la nulidad de la venta de 300-00-00 hectáreas de terreno de uso común, realizada por el comisariado ejidal a favor de un estadounidense.

57 Expediente 717/2000, radicado en el Tribunal Unitario Agrario Distrito 41, en Acapulco, Guerrero, promovido por Banca Serfín, actuando como fideicomisario de una persona de nacionalidad alemana, en el que demandó el mejor derecho a la posesión de un terreno en contra de un estadounidense y de un mexicano. 
En el primer caso, pueden demandar inversionistas de Canadá y Estados Unidos de América. En el segundo, pueden demandar inversionistas nacionales de estados que han celebrado Apris con el gobierno de México.

Tercera. El caso Punta Banda refleja objetivamente que la tenencia de la tierra por extranjeros, por medio de fideicomisos, también puede generar conflictos internacionales.

Cuarta. Estas circunstancias motivan la reflexión por cuanto a la necesidad de comprender la magnitud y trascendencia que significa para los mexicanos la celebración de tratados internacionales, y de formar parte, como país, de organismos comerciales que se constituyen en el contexto de la globalización económica.

\section{SUGERENCIAS}

Primera. Que en planes de estudios universitarios, particularmente en las facultades de derecho y economía, de manera obligatoria, se curse la asignatura de tratados comerciales y de inversión, y los mecanismos de solución de controversias derivados de los mismos.

Segunda. Que tanto la Cámara de Diputados como la de Senadores, al momento de tratar lo relativo al análisis, discusión y aprobación de cualquier tratado internacional, así como el propio Poder Ejecutivo federal, tomen en cuenta previamente, la opinión de especialistas en la materia.

Tercera. A la luz de los laudos dictados por el CIADI en contra de México, particularmente el caso Metalclad, en relación con el caso Punta Banda, es recomendable que el gobierno de México revise con un real sentido jurídico y nacionalista los alcances y consecuencias del TLCAN (Tratado de Libre Comercio de América del Norte), OMC (Organización Mundial del Comercio) y ALCA (Acuerdo de Libre Comercio para las Américas), entre otras expresiones de la globalización.

\section{BIBLIOGRAFÍA}

BOLAÑOS LinaReS, Rigel, Inversión extranjera, México, Porrúa, 2002. CRUZ MIRAMONTES, Rodolfo, El TLC: controversias, soluciones y otros temas conexos, México, McGraw-Hill, 1997. 
LÓPEZ-AYLLÓN, Sergio, Las transformaciones del sistema jurídico y los significados sociales del derecho en México. La encrucijada entre tradición y modernidad, México, UNAM, 1997.

ORTIZ AHLF, Loretta et al., Aspectos jurídicos del Tratado del Libre Comercio de América del Norte y sus acuerdos paralelos, 1a. reimpr. de la 2a. ed., México, Themis, 2000.

PACHeCo MARTíneZ, Filiberto, Derecho de la integración económica, México, Porrúa, 1998.

ROBLES FARÍAS, Diego, El régimen jurídico de los extranjeros que participan en sociedades mexicanas, México, Themis, 2000.

Rodríguez GonzÁlez-VAladeZ, Carlos, México ante el Arbitraje Comercial Internacional, México, Porrúa, 1999.

Rubio, Luis, ¿Cómo va a afectar a México el Tratado de Libre Comercio?, México, Fondo de Cultura Económica, 1994.

SÁNCHEZ VÁZQUEZ, Rafael, La libertad e igualdad jurídica como principios generales del derecho, México, Porrúa, 1995.

-, Metodología de la ciencia del derecho, 5a. ed. corr. y aum., México, Porrúa, 2001.

SEPúlvedA, César, Derecho internacional, 17a. ed. act., México, Porrúa, 1991.

SERRANO Migallón, Fernando, El mecanismo de solución de controversias, en Witker, Jorge (coord.), Resolución de controversias comerciales en América del Norte, 1a. reimpr. de la 1a. ed., México, UNAM, Instituto de Investigaciones Jurídicas, 1997.

SIQUEIROS, José Luis, El arbitraje en los negocios internacionales de naturaleza privada, México, Escuela Libre de Derecho, 1992.

Vives ChILlidA, Julio A., El Centro Internacional de Arreglo de Diferencias relativas a Inversiones (CIADI), España, McGraw-Hill, 1998. WITKER, Jorge (coord.), Resolución de controversias comerciales en América del Norte, 1a. reimpr. de la 1a. ed., México, UNAM, Instituto de Investigaciones Jurídicas, 1997.

- Aspectos regulatorios-institucionales de la inversión extranjera directa, en Kaplan, Marcos y Manrique Campos, Irma (coords.), Regulación de flujos financieros internacionales, 2a. ed., México, UNAM, Instituto de Investigaciones Jurídicas, 2002. 
1. Fuentes de investigación hemerográfica

Diario Oficial de la Federación, 6 de enero de 1992.

, 26 de febrero de 1992.

-, 22 de diciembre de 1992.

, 20 de diciembre de 1993.

, 19 de marzo de 1997.

, 23 de enero de 1998.

Expediente 1145/2000, radicado en el Tribunal Unitario Agrario Dto. 28. 717/2000, radicado en el Tribunal Unitario Agrario Dto. 41. Proceso, núm. 1258, 10 de diciembre del 2000.

\section{Internet}

http://www.wordbank.org/icsid

http://www.starmedia.com

http://www.economía-snci.gob.mx

http://www.ran.gob.mx

\section{Legislación}

Constitución Política de los Estados Unidos Mexicanos.

Ley Agraria.

Ley de Inversión Extranjera.

Ley de Nacionalidad.

\section{Otros documentos}

Artículo 25.1 del Convenio de Washington.

Doc.ICSID/2, par.24.

Doc.ICSID/5 Rev.1.

Oficio número DGR/454/01. Registro Agrario Nacional. DGCJN.511.06.243.01. Secretaría de Economía. 